\title{
Acceptance and Commitment Therapy (ACT) to Improve Educators Self-Acceptance of Children with Special Needs
}

\author{
Muya Barida, Dian Ari Widyastuti
}

Universitas Ahmad Dahlan, Yogyakarta, Indonesia

moza_barid@yahoo.com

Submitted: 2019-08-27, Revised: 2019-10-29, Accepted: 2019-11-26

\begin{abstract}
Children with Special Needs are children with disabilities in the development of life due to disruption (mental, intellectual, emotional, social, physical) in the social-social, career, and academic fields, so they need special services and are different from children in general. This study aims to determine the effectiveness of Acceptance and Commitment Therapy (ACT) to increase the self-acceptance of educators towards Children with Special Needs. This study uses an experimental approach to the design of one group pretest-posttest. The study was conducted on teachers who are members of the HIMPAUDI Sleman District, who were randomly selected and obtained as many as 27 teachers. Data analysis was performed using the T-Test technique. Based on the results of the study, it appears that the self-acceptance of educators towards Children with Special Needs before and after the training on Acceptance and Commitment Therapy (ACT) increases, but the increase is less significant. Conclusion The Acceptance and Commitment Therapy (ACT) program is less effective in improving the self-acceptance of educators towards Children with Special Needs. Based on these results, it needs to be followed up with direct assistance or assistance in schools for educators who systematically help Children with Special Needs.
\end{abstract}

Keywords: Acceptance and Commitment Therapy (ACT); Children with Special Needs; Self-Acceptance Educator

\section{Introduction}

Every parent expects normal conditions for their children. Desires sometimes do not match reality, especially for parents in the presence of children belonging to Children with Special Needs. Children with Special Needs are differences in children's abilities that interfere with learning and other activities that require special services. Children with Special Needs includes (a) Speech and language disorders, which have problems in expressing themselves or understanding others, (b) Mental retardation, which causes children to develop more slowly than other children, (c) Emotional disabilities, who experience antisocial or other. behavioral problems, (d) learning disabilities, distorting messages from their perception, and (e) physical disabilities, who have vision problems, cerebral palsy, or other conditions (Jamaica Association for Deaf, 2015).

Some categories of special needs include: (a) impaired speech, (b) visual or visual difficulties, (c) intellectual disabilities, (d) hearing difficulties, (e) disorders of the musculoskeletal system, (f) complex structural disorders, (g) Emotional disorders and autism children. Children with Special Needs types can stand alone, but can also consist of several types (Valeeva \& Kulesza, 2016).

The Directorate of Special Schools Development and the Directorate General of Primary and Secondary Education Management of the Ministry of National Education stated the Children with Special Needs grouping included hearing impairment, visual impairment, mental retardation (al down syndrome), mild mental retardation (IQ $=50-70$ ), moderate mental retardation (IQ $=25-50$ ), severe mental retardation (IQ below 25), potential unique talents (multiple intelligences: language, logic mathematics, visual-spacial, body-kinesthetic, musical, interpersonal, intrapersonal, natural, spiritual), learning difficulties (al hyperactivity, ADD or ADHD, dyscalculia (arithmetic disorders), dyslexia (reading disorders), dysgraphia (writing disorders), dysphasia (dysphasia (writing disorders) speech disorders), dyspraxia (motor disorders), slow learning (IQ $=70-90)$, autism, indigo, and victims of drug abuse 
(Prasetyaningrum, Saraswati, \& Firmanto, 2017). Down syndrome is a genetic disorder that is the structure of chromosomes to form trisomy, causing mental retardation (Lane, Reed, \& Hawranik, 2019). Autism is a developmental disability that significantly affects verbal and non-verbal communication and social interaction (Durkin et al., 2017).

Based on this opinion, Children with Special Needs is a child with life development obstacles due to disorders (mental, intellectual, emotional, social, physical) in the socialpersonal, career, and academic fields, so that services are needed and are different from children in general. Abnormalities or weaknesses experienced by Children with Special Needs are not only accepted by parents and educators as parents at school. The process of taking the conditions of Children with Special Needs for educators is not easy. Lack of access to knowledge, understanding, and skills of educators towards the diversity of students classified as Children with Special Needs affects the level of acceptance (self-acceptance) of various conditions of Children with Special Needs with healthy children. Often, educators compare and force students' abilities to follow the demands imposed at school. This shows that educators' self-acceptance of the condition of Children with Special Needs is still lacking.

Self-acceptance is essential for individuals in living their lives. Self-acceptance is not to tolerate everything that makes an individual sad, but to realize the strength, they have to be happy, healthy, and prosperous (Plexico, Erath, Shores, \& Burrus, 2019). Self-acceptance can make individuals experience permanent changes. Self-acceptance is self-esteem and selfconfidence (Xu, Oei, Liu, Wang, \& Ding, 2016). Self-acceptance involves the knowledge and belief that when an individual feels the pain, he can overcome anxiety until it gets better. Individuals can accept things that are not following their expectations. Furthermore, selfacceptance is a realism or respect for the reality of the state of self. (De Nardo, Gabel, Tetnowski, \& Swartz, 2016).

Based on the description above, it is necessary to conduct training for educators of Children with Special Needs so that educators can accept the conditions of Children with Special Needs unconditionally. This opinion is supported by Tanyi, who explains that Children with Special Needs are children who show one of several specific situations that require a particular educational need and approach related to efforts to facilitate academic, social, and emotional development (Tanyi, 2016). Educator training in this study uses the Acceptance and Commitment Therapy (ACT) approach. Acceptance and Commitment Therapy (ACT) is one of psychotherapy using the principles of acceptance and commitment to improving behavior.

Acceptance and Commitment Therapy (ACT) through the development of procedures such as self-acceptance as context, and cognitive defusion, ACT helps clients to recognize transcendental self that is not evaluated or built on personal experience (Hacker, Stone, \& MacBeth, 2016). ACT is proven effective in decreasing experiential avoidance and thought suppression of adults with negative experiences of paternal figures (Mubina, 2016). Furthermore, the effectiveness of ACT is proven to apply to families with problems caring for families with mental disorders (Putra, Hamdani, \& Supriati, 2017).

At ACT, the six procedures are training for educators. Six methods include selfacceptance, cognitive diffusion, being present, self as context, life values, and commitment. In this ACT, educators of Children with Special Needs will learn how to accept thoughts and feelings related to the reality faced by those who might previously be rejected. In addition to receiving a commitment to act, it is also essential. This commitment involves educating Children with Special Needs to make conscious decisions about what is necessary for their lives and those of others. Acceptance as a process increases the overall acceptance of subjective experiences, thoughts, sensations, beliefs, and feelings that cause distress, then seeks to increase the desired behavioral changes to improve the quality of life 
(Kusumawardhani \& Poerwandari, 2018). While the principle of cognitive defusion as a process for observing the mind so that the impact and influence are less than when experiencing a fusion of thought. The third principle is mindfulness; Individuals are expected to be able to give focus and be fully involved in what they are doing in the present.

The fourth principle of observing self is personal experience, not just emotions, thoughts, roles, sensational impulses. All aspects can change regularly so that they become part of the experience, not the beliefs and essence of the individual. The fifth principle is Value. The value principle aims to clarify the things that are most important for individuals in life, the desires expected in life, and significant and meaningful lives. The last principle is commitment. In this principle, the individual is expected to be able to set life goals guided by values deemed necessary so he can take dynamic behavior to achieve them (Hayes, Strosahl, \& Wilson, 2009).

From this explanation, researchers are interested in researching Acceptance and Commitment Therapy (ACT) training for educators of Children with Special Needs with the aim of proving the effectiveness of Acceptance and Commitment Therapy (ACT) in selfacceptance of educators.

\section{Methods}

This experimental study with One group pretest-posttest design. Furthermore, the research target for educators who are members of the HIMPAUDI / Teachers' Early Childhood Association in Sleman Regency was chosen randomly by 27 teachers. All HIMPAUDI members have the opportunity to attend the Reception and Commitment Therapy (ACT) training. This study uses 20 items of self-acceptance instruments for Educators of Children with Special Needs, before and after the Acceptance and Commitment Therapy training. Data analysis techniques using the T-Test, the results are seen through descriptive statistics based on average values. Category educator self-acceptance 20-40 selfacceptance is low, 41-60 medium self-acceptance, and 61-80 high self-acceptance.

The training was carried out for eight sessions. The training material provided and the methods applied, and training include: (a) Introduction to the types of Children with Special Needs with the method of Games and Sharing active knowledge, (b) Causes of Children with Special Needs with the method of Games and Sharing active knowledge, (c) Weaknesses and strengths of Children with Special Needs with the method of Games and Sharing active knowledge, (d) Reflection on weaknesses and strengths of Children with Special Needs with the method of Games and Sharing active knowledge, (e) Self Development of Children with Special Needs using the Focus Group Discussion (FGD) method through the Experiential learning model, and self-acceptance reflection on Children with Special Needs using the Focus Group Discussion (FGD) method through the Experiential learning model.

\section{Results and Discussion}

The condition of educators' self-acceptance for Children with Special Needs before and after the Acceptance and Commitment Therapy (ACT) training has improved, but the increase is not too significant. The hypothesis in this study was carried out using a T-Test. The results of data calculation before and after the Acceptance and Commitment Therapy training are shown in Table 1 . 
Table 1. Results of Changes in Pretest and Posttest Scores

\begin{tabular}{cccccccccc}
\hline Pair & \multicolumn{2}{c}{ Pretest } & \multicolumn{2}{c}{ Posttest } & & N & & \multicolumn{2}{c}{ Pretest/posttest } \\
\cline { 2 - 3 } \cline { 8 - 10 } & $\mathrm{M}$ & $\mathrm{Sd}$ & $\mathrm{M}$ & $\mathrm{Sd}$ & & & $\mathrm{M}$ & $\mathrm{Sd}$ \\
& 59,81 & 2,84 & 61,44 & 4,73 & 27 &, 175 & 1,62 & 6,07 \\
\hline
\end{tabular}

In table 1 , the pretest results of the average value of educators' self-acceptance reached 59.81. The average posttest self-acceptance score was 61.44. The results of the pretest showed that the educator's self-acceptance was in the medium category. The posttest results showed the self-acceptance of educators towards Children with Special Needs in the high grade.

It was concluded that the Acceptance and Commitment Therapy (ACT) training could increase the self-acceptance of educators towards Children with Special Needs. However, the significance level of the research was 0.175, indicating that the Acceptance and Commitment Therapy (ACT) training was less effective in increasing the self-acceptance of educators towards Children with Special Needs. Based on the results obtained by the Acceptance and Commitment Therapy (ACT) training, it is useful to increase the self-acceptance of educators towards Children with Special Needs, although it is not significant. The shows the Acceptance and Commitment Therapy (ACT) training is a series of activities to facilitate individuals to do some planning, carry out situations that are full of sincerity without preconditions. The ACT approach is also useful in improving work performance, reducing work stress, increasing innovation, increasing job acceptance (Pots et al., 2016).

Acceptance and Commitment Therapy (ACT) is used to help present relationships with the sensation of experiential knowledge, not just verbal instructions. Trainees are invited to see themselves as a context of ongoing experiences involving all things that occur in the skin, emotions, thoughts, memories, and bodily sensations, without excessive verbal involvement and control. The aim is to reduce avoidance of experience and move towards meaningful parts of life or to help trainees who have fallen into rigid ways of thinking and behave more flexibly psychologically and behaviorally (Hallis, Cameli, Bekkouche, \& Knäuper, 2017).

ACT's statement supports this opinion as an approach to contextual behavior that seeks to change the function of experience (including thoughts, feelings, and emotions) by changing the context in which thoughts, feelings, and emotions occur, rather than their form or frequency. The exercise uses experience training and metaphors (changing the verbal context in which events occur). The ACT principle is to look for meanings of influence and function that result in the development of psychological flexibility (Plumb \& Vilardaga, 2010).

The ACT Domain consists of six domains, namely acceptance, confusion, values, contact with the present, self as context, and committed action. These six domains are part of ACT training (Moran, 2011).

Furthermore, after training continues with monitoring and evaluation activities in schools to find out the development of educators in dealing with students classified as Children with Special Needs. Through ACT training, educators can accept the conditions of Children with Special Needs unconditionally. Monitoring and evaluation also assist educators 
who have difficulty realizing a series of programs planned by educators and developing the potential of students classified as Children with Special Needs.

The role of educators and parents is significant for the development of cognition, physical, and psychosocial children with special needs. The purpose of parents is substantial in the success and achievement of children (Levitt, List, Metcalfe, \& Sadoff, 2016). Also, parents have a role in the formation of a child's character because the creation and development of characters affect relatively long conditions. Also, parents are a model or role model for children to learn, develop, and get protection. (Wulandari \& Kristiawan, 2017).

The role of parents consisting of father and mother. Fathers as family leaders, protectors, breadwinners, educators, and provide security for family members. Mothers take care of the household, care for children, educate children, protect, and as additional breadwinners for the family. In general, parents experience a process of disappointment, rejection, and anger over the condition of their children with special needs (Yoga, Suarmini, $\&$ Prabowo, 2015). This incident makes parents often avoid reality and not perform the role of parents to the fullest.

The Kubler-Ross model says the process of accepting a parent or family to a child with special needs through five stages, namely (a) Denial and isolation, (b) Anger or anger stage, (c) Bargaining or bargaining stage, (d ) Depression or depression stage, (e) Acceptance or acceptance stage (Pomeroy \& Garcia, 2008). Parents' experiences, beliefs, and expectations are essential components to support good learning outcomes for children (Afolabi, 2014). Parents who have a strong belief that children have and can develop potential, expectations about the child's possible success without imposing achievements and children's development experiences from time to time, can directly or indirectly increase the success of Children with Special Needs.

Educators or several teachers experience the same situation. Parents often behave and give in to educators. When children are in school, parents assume that the teacher or educator has the responsibility to educate their children. Educators are sometimes unprepared for the situation of students who, as Children with Special Needs, with Acceptance and Commitment (ACT) training through several admissions processes, Educators with Children with Special Needs can accept themselves from Children with Special Needs.

\section{Conclusions and Suggestions}

Based on the results of this study, this shows that the Training on Acceptance and Commitment of Therapy (ACT) for Educators of Children with Needs can be used to increase educators' self-acceptance, although it is not significant. The ability of educators to identify the possibility of students, including children with Special Needs at PAUD level, still needs to be significantly improved. Therefore it is necessary to make ongoing efforts such as mentoring or mentoring in schools for teachers who accompany children with special needs so that all educators can accept the conditions of all children, not only "normal" children but Children with Special Needs. Also, provide other interventions according to the type of "specificity" of students with special needs.

\section{References}

Afolabi, O. (2014). Parents' Involve and psycho-educational Development of Learners with Special Educational Needs (SENs): An Empirical Review. International Journal of Early Childhood Special Education, 6(2), 177-203.

De Nardo, T., Gabel, R. M., Tetnowski, J. A., \& Swartz, E. R. (2016). Self-acceptance of stuttering: A preliminary study. Journal of Communication Disorders, 60, 27-38.

Durkin, M. S., Maenner, M. J., Baio, J., Christensen, D., Daniels, J., Fitzgerald, R., ... Van 
Naarden Braun, K. (2017). Autism spectrum disorder among US children (2002-2010): socioeconomic, racial, and ethnic disparities. American Journal of Public Health, 107(11), 1818-1826.

Hacker, T., Stone, P., \& MacBeth, A. (2016). Acceptance and commitment therapy-do we know enough? Cumulative and sequential meta-analyses of randomized controlled trials. Journal of Affective Disorders, 190, 551-565.

Hallis, L., Cameli, L., Bekkouche, N. S., \& Knäuper, B. (2017). Combining Cognitive Therapy With Acceptance and Commitment Therapy for Depression: A Group Therapy Feasibility Study. Journal of Cognitive Psychotherapy, 31(3), 171-190.

Hayes, S. C., Strosahl, K. D., \& Wilson, K. G. (2009). Acceptance and commitment therapy. American Psychological Association.

Kusumawardhani, S. J., \& Poerwandari, E. K. (2018). Efektivitas Acceptance Commitment Therapy dalam Meningkatkan Subjective Well-Being pada Dewasa Muda Pasca Putusnya Hubungan Pacaran. Jurnal Ilmiah Psikologi MIND SET, 9(01), 78-97.

Lane, A. M., Reed, M. B., \& Hawranik, P. (2019). Aging Individuals With Down Syndrome and Dementia as Teachers: Learnings from Staffin a Developmental Disability Program in Long-Term Care. Journal of Gerontological Nursing, 45(5), 17-22.

Levitt, S., List, J., Metcalfe, R., \& Sadoff, S. (2016). Engaging Parents in Parent Engagement Programs. Society for Research on Educational Effectiveness.

Moran, D. J. (2011). ACT for leadership: Using acceptance and commitment training to develop crisis-resilient change managers. International Journal of Behavioral Consultation and Therapy, 7(1), 66.

Mubina, N. (2016). Efektivitas Acceptance Commitment Therapy Dalam Menurunkan Experiential Avoidance Pada Dewasa Muda Dengan Pengalaman Negatif Terhadap Figur Ayah. PSYCHOPEDIA: Jurnal Psikologi Universitas Buana Perjuangan Karawang, 1(1).

Plexico, L. W., Erath, S., Shores, H., \& Burrus, E. (2019). Self-acceptance, resilience, coping and satisfaction of life in people who stutter. Journal of Fluency Disorders, 59, 52-63.

Plumb, J. C., \& Vilardaga, R. (2010). Assessing treatment integrity in acceptance and commitment therapy: Strategies and suggestions. International Journal of Behavioral Consultation and Therapy, 6(3), 263.

Pomeroy, E., \& Garcia, R. (2008). The grief assessment and intervention workbook: A strengths perspective. Nelson Education.

Pots, W. T. M., Fledderus, M., Meulenbeek, P. A. M., Peter, M., Schreurs, K. M. G., \& Bohlmeijer, E. T. (2016). Acceptance and commitment therapy as a web-based intervention for depressive symptoms: randomised controlled trial. The British Journal of Psychiatry, 208(1), 69-77.

Prasetyaningrum, S., Saraswati, P., \& Firmanto, F. (2017). School Readiness Siswa Berkebutuhan Khusus Di Kelas Inklusi Tingkat Sekolah Dasar Kota Batu. Jurnal Psikologi Perseptual, 2(1), 48-67.

Putra, I. P. G. Y. S., Hamdani, N., \& Supriati, L. (2017). Influence Of Acceptance And Commitment Therapy On The Family's Burden In Treating People With Mental Disorders. NurseLine Journal, 2(2), 126-133.

Tanyi, M. E. (2016). Psychological Evaluation of Attitudes of Both Primary Teachers and 
Special Needs Children towards Each Other in a Regular School in Yaoundé-Cameroon. Journal of Education and Practice, 7(6), 63-73.

Valeeva, R. A., \& Kulesza, E. M. (2016). Education for Persons with Special Needs: Polish and Russian Experience. International Journal of Environmental and Science Education, 11(7), 1619-1629.

Wulandari, Y., \& Kristiawan, M. (2017). Strategi Sekolah dalam Penguatan Pendidikan Karakter Bagi Siswa dengan Memaksimalkan Peran Orang Tua. JMKSP (Jurnal Manajemen, Kepemimpinan, Dan Supervisi Pendidikan), 2(2).

Xu, W., Oei, T. P. S., Liu, X., Wang, X., \& Ding, C. (2016). The moderating and mediating roles of self-acceptance and tolerance to others in the relationship between mindfulness and subjective well-being. Journal of Health Psychology, 21(7), 1446-1456.

Yoga, D. S., Suarmini, N. W., \& Prabowo, S. (2015). Peran Keluarga Sangat Penting dalam Pendidikan Mental, Karakter Anak serta Budi Pekerti Anak. Jurnal Sosial Humaniora, $8(1), 46-54$. 
